\title{
Toplumsal Hareketler ve Ortak Düşman Algısı: Suriye İhvanı ve HAMAS
}

\author{
Social Movements and Comman Enemy Perception: Syrian Muslim \\ Brotherhood and HAMAS
}

Bulut GURPINAR ${ }^{1}$

\begin{abstract}
ÖZET
Toplumsal hareket, iktidara ve mevcut düzene karşı kolektif, organize bir karşı çıkış olarak tanımlanabilir. Toplumsal hareketler içerisinde i̇slamcı hareket, İslamcı bir devlet kurmaya çalışan ve İslam bayrağı altında birleşen grupları tanımlamak için kullanılmıştır. Muhalif hareketler içerisinde önemli bir yere sahip olan İhvan (Ihvan-ül Müslimin/ Müslüman Kardeşler) örgütü, bu hareketler içerisinde önemli bir geçmişe sahiptir. Arap ayaklanmalarının ardından kimi ülkelerde iktidara geldikten sonra gücünü kaybederken, kimilerinde de muhalefetin önemli bir unsuru olmuştur. Çalışma, aynı ideolojik kökenden beslenen iki farklı yapı olarak karşımıza çıkan Suriye ihvanı ve HAMAS'ı toplumsal hareketler çerçevesinde amaçları, yapısı, şiddete yönelik tutumu, politik konumu, kamuoyu desteği açısından karşılaştırmayı amaçlamaktadır. Örgütlerin pratiğinin birbirlerinden ne kadar farklı olduğu ve bu farklılığın altında yatan nedenlerin ne olduğu yanıtlanmaya çalışııı̧ anahtar sorular arasındadır. Çalışmada, öncelikle iki örgüt toplumsal hareket olarak tarihsel açıdan yaşadıkları dönüşümlerle karşılaştırılmış, politik tutumları ve konumları incelenmiştir. Ardından bugün gelinen noktada özellikle Arap ayaklanmalarının da etkisiyle iki örgütün politik konumlarındaki değişim ve farklııklar ortak düşman algısı yaratma açısından ele alınarak değerlendirilmiştir.
\end{abstract}

Anahtar Kelimeler: İhvan/Müslüman Kardeşler, Suriye İhvanı, HAMAS, Toplumsal Hareketler, Ortak düşman algısı.

\section{GiRiş}

Suriye İhvanı, Suriye'deki çatışmalar devam ederken, başta Halepliler olmak üzerine bütün Suriyelilere seslenmiş ve çözüm önerilerini sıralamıştır. Bölgeye yönelik her türlü gizli ya da açık dış müdahalenin ve

\begin{abstract}
The social movement can be described as a collective and organized opposition to the power and the status quo. The Islamic movement, within the context of the social movements, is formed by groups who are united under the Islamic flag and work for establishing an Islamic state. Having a significant role in the opposition movements, Ikhwan (Ikhvan-ul Muslims / Muslim Brotherhood) organization has an important history in these movements. After the Arab uprisings, while it fell into decline after coming into power in some countries, in others, it became an important factor for the opposition. The aim of this paper is to compare the two different structures living on the same ideological root, Syrian Ikhwan with HAMAS, in terms of their aims, structure, attitude towards violence, political position and public support in the framework of Islamic movements. The key questions that are addressed in this paper are how different the practices of the organizations and the reasons underlying these differences are. In this study, first, from a historical point of view the two organizations are compared in terms of the transformations they have experienced as social movements, their political attitudes and positions are analyzed. Then, the changes and differences in the current political positions of these two organizations which are influenced both especially from the Arab uprisings are evaluated in terms of creating the perception of a common enemy.
\end{abstract}

Keywords: Ikhwan/Muslim Brotherhood, Syrian Muslim Brotherhood, HAMAS, Social Movements, Common Enemy. 
içeren bir siyasi programın acil olarak tasarlanması, yerlerinden edilmiş Suriyelilerin güvenli biçimde ülkelerine dönmelerini sağlayacak bir takvim oluşturulmasını içeren taleplerini yayımlamıştır (AA, 2016). Bugün gelinen noktada muhalif unsurlardan biri olarak Suriye İhvanı, ülkenin geleceğine talip olanlar arasında sayılmasına karşın kamuoyundan gereken desteği sağlayamamıştır.

Yakın coğrafyada, Filistin'de 2004 yılının Kasım ayında Yaser Arafat'ın ölümüyle başlayan ve Ocak 2005'te Mahmud Abbas'ın devlet başkanlığıyla devam eden siyasî süreç, 25 Ocak 2006'da gerçekleşen parlamento seçimlerinde HAMAS'ın zaferiyle sonuçlanmıştır. HAMAS'ın 2006 yılında seçimleri kazanması ile ilk kez bir İslamcı hareketin serbest ve demokratik seçim yoluyla iktidara talip olması, Arap dünyasında önemli bir dönüm noktası olmuştur. Bugün gelinen noktada, HAMAS Gazze şeridinin kontrolünü ele geçirerek El-Fetih üyelerini ve Filistin yönetimini bölgeden çıkarmıştır.

HAMAS'ın seçimlerden birinci parti olarak çıkmayı başararak ülkenin bir bölümünü yönetimi altında birleştirmesine karşılık Suriye İhvanı́nın kamuoyundan belirgin bir destek alamaması ilgi çekicidir. Suriye ve Filistin'in farklı tarihsel geçmişleri, buna bağlı olarak farklı kamuoyu tercihleri, iki ülkenin farklı jeopolitik konumları ve farklı siyasal yapıları vardır. Suriye'nin toprak bütünlüğüne karşılık Filistin'de sınırlar neredeyse her zaman tartışmalı olmuştur. Suriye'deki merkezi hükümetin yerine Filistin'in böyle bir yönetim geçmişi yoktur. Kaldı ki, Suriye'de çatışmalarla birlikte birçok farklı muhalif unsur yönetime talip olmuş, bölgede iç savaş ve bölünme gündeme gelmiştir. Suriye iç̧ Savaşı "vekalet savaşı" olarak günümüzde uluslararası güçlerin müdahalesine açık hale gelmişken, İsrail-Filistin sorunu uzun zamandır uluslararası bir sorundur. Her iki sorunda da uluslararası güçlerin katılımları, pozisyonları karşılaştırılan örgütlerin güçlenmelerinde/güç kaybetmelerinde önemli değişkenlerdendir.

Bu çalışma, İhvan hareketinin içerisinden çıkan iki örgütü, HAMAS ve Suriye İhvanı'nı toplumsal hareket olarak karşılaştıran ilk çalışma olmasının yanı sıra ortak düşman yaratma siyaseti açısından her iki örgütü değerlendirerek alana katkıda bulunmayı hedeflemiştir. Öncelikle, amaç 1928'de Mısır'da kurulan İhvan hareketinin bir İslamcı örgüt olarak iki farklı ülkedeki konumlarını karşılaştırmaktır. Çalışma iki örgütü, kamuoyu desteği sağlama açısından sahip oldukları olanakları ortak düşman anlayışı çerçeve- sinde karşılaştırmayı hedeflemiştir. Filistin'de uzun zamandan beri devam eden İsrail sorunu kamuoyu desteğinde önemli bir değişken olabilir. HAMAS'ın görece başarısında "ortak düşman" algısının payı ne olabilir, Suriye İhvanı́nın ortak düşman yarat(a) maması, yeterince kamuoyu desteği sağlayamamasının nedenlerinden biri olabilir mi soruları çalışmada iki örgütün izlediği benzer ve farklı siyasetlerle yanıtlanmaya çalışılacaktır.

$\mathrm{Bu}$ çerçevede çalışmada öncelikle İhvan'ın toplumsal hareketler içerisinde yeri tartışılmış, Suriye İhvanı ve HAMAS toplumsal hareketlerin doğuş ve birleşme, bürokratikleşme/radikalleşme aşamaları ile ele alınarak tarihsel açısından karşılaştırıımıştır. Bu tarihsellik içerisinde kamuoyunun oluşturulmasında izlenen politikalardaki farklııılara değinilmiştir. Son olarak iki örgütün politika ve söylemlerinde "ortak düşman" algısının yeri ve kamuoyu oluşturmadaki durumu tartışılmıştır.

\section{TOPLUMSAL HAREKETLER VE IHVAN}

Toplumsal hareket kavramı, başlangıçta statükoya karşı çıkan yeni siyasal güçler için toplumsal protesto hareketlerini nitelendirmek amacıyla adeta şemsiye bir kavram olarak neredeyse her türlü ayaklanma için kullanılmaya başlanmıştır. Ancak Alain Touraine (2000: 125)'e göre toplumsal hareketin en önemli ayırt edici yönü, toplumsal bütünleşmeyi ya da ekonomik ilerlemeyi engellediği düşünülen eylemlere karşı olması ve toplumun genel yönelimlerini ortaya koymasıdır. Toplumsal hareket, otoritelere, iktidar sahiplerine veya kültürel inançlara ve pratiklere karşı kolektif, organize, sürdürülebilir ve kurumsal olmayan bir meydan okumadır (Goodwin ve Jasper, 2003: 3). Bu kolektif yapıya vurgu yapan Giddens'in tanımıyla (2006: 868), toplumsal hareket, yerleşik alanın dışındaki toplu eylemler yoluyla, ortak bir çıkarı korumak ya da ortak bir hedefe erişmeyi sağlayabilmek için girişilen toplu bir çabadır. Bu kolektif hareket, içerisinden çıktığı toplumdan ve toplumsal gelişmelerden doğrudan etkilenir. Bu yönüyle, toplumsal hareketler üzerine ilk sistematik düşünce ya da yaklaşımın 18 . yüzyıl sonları, 19. yüzyılın başlarından itibaren ortaya çıkmaya başlaması da tesadüf değildir. Bunun nedeni, hızlı kentleşme, göç, kapitalist toplumsal ilişkiler, metalaşma sürecinin toplumda ciddi kargaşalara yol açması ve bunun sonucunda da vergi eylemlerinin, ekmek eylemlerinin, seçim eylemlerinin baş göstermesidir (Çetinkaya, 2008: 28). Bu eylemlilik hali ve statükoya karşı çıkma durumunun, sosyal gelişmeler- 
le iç içe oluşu, toplumsal hareketlerin kendi içerisinde ayrışmasını da beraberinde getirmiştir.

Toplumsal hareketlerin bir parçası olarak İslamcı hareket kavramı Quintan Wiktorowicz'in tanımıyla (2004: 2), yayılma hareketleri, terörist gruplar, İslamcı semboller ve kimlikler içinde kökleşmiş kolektif eylemler, İslamcı bir devlet kurmaya çalışan açıkça politik hareketler dahil olmak üzere "İlam" bayrağı altında sıkça ortaya çıkan çatışmanın çeşitliliğini barındırmaktadır. İslamcı maneviyatın kolektif çabalarla teşvik edilmesini sağlayan bu grupların, zamanlama ve taktikleri yerel bağlamlara göre değişebilirken, birbirleriyle tutarlılık sergileyen yaygın araçları vardır. Sidney Tarrow'un (1994: 37) öne sürdüğü gibi, bu tür araçlar, farklı aktörlerin farklı anlarda ve yerlerde kullanabilecekleri modüler protesto biçimlerini yeniden modellemeleri açısından çok yaygındır. Bu gruplar genellikle aktivizmi teşvik etmek için bir haksızlık duygusu uyandıracak şekilde tasarlanan sembol, söylem ve pratiğe dayanan seferberlik çerçeveleri üretmektedir. Bu, İslamcı sosyal hareketlerin dinamikleri, süreci ve örgütlenmesinin, "İslam"ın özgüllüğünü, bir anlam, kimlik ve kolektif eylemin temeli olarak kabul eden bir çatışmanın önemli unsurları olarak anlaşılabileceğini göstermektedir. Wiktorowicz'in belirttiği gibi (2004: 3), İslam'ın ideolojik bir dünya görüşü olarak düşünülen bileşenleri ve ilhamı, İslamcı hareketi diğer toplumsal hareket örneklerinden farklı kılsa da kolektif eylemin kendisi başka bir deyişle, İslamcı hareket sui generis değildir. İslamcı ideolojiye göre, sosyo-ekonomik ve siyasal sorunların nedeni İslam köklerinden uzaklaşmadır ve bunun çözümü İslam'ın özünde aranmalı, devlet İslamcı ideoloji ekseninde düzenlenmelidir. Kur'an ve Sünnete dönüş olarak özetlenebilecek bu yaklaşımda hedef şeriatla yönetilen bir topluluk oluşturmak iken, ortak düşman "Allah'a direnen herkestir" (Esposito, 2002: 106). Ancak dünya üzerindeki İslamcı hareketler monolitik bir yapıda değildir, her ne kadar İslam ortak paydasında görülebilecek unsurlar taşısalar da birbirlerinden farklı yöntem ve örgütlenme modelleri geliştirdikleri görülmektedir. Bu farklılığın en temel nedeni, İslamcı ideolojinin çıkış noktasını oluşturan Kur'an ve Sünnet'in yorumlanmasındaki farklııktan kaynaklanmaktadır. Ayrıca toplumsal hareketlerin amaçları benzer olsa da buna ulaşmada kullandıkları araçlar zamanla değişebilir, birbirinde farklı olabilir. Bir kısmı mevcut siyasal sistemde reform yapmaya çalışırken, bir kısmı yalnızca değişiklik talebinde bulunur, bir kısmı ise siyasal değişimin tümü yerine kültürel açıdan değişim talebi ile yetinebilir (Chris- tiansen, 2009: 4). Bernard Lewis'e göre (1986:144), İslamcı örgütler, Peygamberin farklı yaşam kesitlerini öne çıkaran bir ayrımla, ılımlı (quietist) ve köktenci (radical) gelenek olarak iki grupta incelenebilir. Ilımlılar, Peygamberin devlet adamı olduktan sonra Medine dönemini örnek alırken, aktivistler Mekke dönemindeki konumunu benimserler. Ilımlı gelenek, iktidarı ele geçirmekten ziyade, iktidarı iyileştirmeye yönelik daha pasif bir siyasal tutum içerisindeyken, radikaller Peygamberin devletin başına geçmeden önce Mekke'deki muhalefetini temel alarak isyancı kimliklerini ön plana çıkartmışlardır. Ancak her ne kadar İslamcı hareket, toplumsal hareketlerle eylem ve yöntem açısından benzeşse de Bayat'ın işaret ettiği gibi (2005: 896), İslamcı hareket, İslamcı aktivizm, politik İslam kavramları birbirlerinden farklı özellikler taşır ve "i̇slamcılığın ampirik gerçekleri, daha karmaşık ve çok yönlü bir yaklaşım benimsenmesini gerektirir".

İslamcı hareketler içerisinde köklü bir geçmişe sahip İhvan hareketi, bu ismi taşıyan veya aynı ilke ve hedefleri benimsemiş olan oluşumlarla, günümüzde 6 kıtada 72 devlete yayılmış en önemli "islamcı muhalefet" gurubunu temsil etmektedir (Karaman, 2007). Olivier Roy (2005), günümüz İslamcı düşüncesinin ve örgütlerinin temellerinden biri olarak Hasan El-Benna tarafından "Kur'an bizim anayasamızdır" diyerek Mısır'da kurulmuş olan İhvan'ı görmektedir. İhvan, ilk olarak Mısır'da 1928 yılında İngiliz manda rejimine karşı bir tepki hareketi olarak kurulmuş, ilk başlarda yalnızca siyasal sistemde değişiklik talebinde bulunmuş bir toplumsal harekettir. İhvan hareketini diğer İslamcı örgütlenmelerden farklı ve önemli kılan, İslamcılar arasında ilk siyasal talepli örgütlenme olmasıdır (Tekin ve Akgün, 2011: 661).

İhvan hareketinin kuruluşundaki amacı El-Benna (1980)'nın şu sözlerinde kendini göstermiştir: “Ey Müslüman Kardeşler! Siz, bir hayır ve yardım kurumu değilsiniz. Bir siyasi parti de değilsiniz. Belirli ve geçici bir gaye için kurulmuş bir teşkilât ta (sic..) değilsiniz... Hükümet kurmak İslâmın bir parçasıdır... şayet karşımıza çıkar, yolumuzda durursanız, Allah bize, kendimizi müdafaa etmeye dair savaş izni vermiştir." Bu temelle İhvan, Mısır'da 1936'dan itibaren İngiliz işgalcilere karşı gösterilerle adını duyurmuş, kısa zamanda etki alanını genişleterek bütün Arap coğrafyasına yayılmıştır (Baroud, 2009:122). Ancak siyasal taleplerden önce ilk amaç eğitim ve sosyal faaliyetler ile toplumu İslam ile düzeltmek olarak benimsenmiştir. Başlangıçta toplumsal ve moral bir hareket olan İhvan, 1947'de Pakistan'ın ilk Müslüman-ulus 
devlet olarak kurulması ve İslam devleti düşüncesinin savunucusu Seyyid Kutub'un İhvan'a verdiği ilhamla siyasi değişim ve/veya reform savunan politik İslam hareketine (İslamcılık) dönüşsmüştür.

Mısır'da kuruluşunun ardından, üye sayıları gitgide artan İhvan, Mısır dışında da şubeler açarak Ortadoğu coğrafyasına yayıımaya başlamıştır. İlk olarak 4 şube ile Suriye'de, 2 şube ile Lübnan'da, daha sonra Filistin, Ürdün ve Sudan'da şubeler açılmıştır. Hareket giderek Pakistan, Güney Sudan ve Afrika gibi Arap toprakları dışında kalan bölgelere de nüfuz etmiştir. Yayıldıkça, bulunduğu coğrafya ve siyasal ortamdan etkilenerek dönüşen İhvan'a ait genel bilgilerin ardından, Suriye ve Filistin kolları (HAMAS), önemli dönüm noktaları ve kamuoyu oluşturma stratejileri açısından sırasıyla incelenebilir.

\subsection{Suriye İhvanı}

Toplumsal hareketlerin gelişimi farklı evrelere ayrılarak incelenebilir: doğuş, birleşim, bürokratikleşme/radikalleşme ve yükselme/gerileme. Öncelikle toplumsal hareketler doğdukları aşamada henüz örgütsellik açısından küçüktürler ve hazırlık evresindedirler. Bu aşamada kolektif eylemden ziyade bireysel eylem bulunur (Christiansen, 2009: 2). Örgütün bu dönemdeki ana hedefi, "birleşim" aşamasına geçmek, taraftarlarını artırarak geniş kitlelere yayılmaktır. Doğuş aşamasından sonra gelen birleşim aşamasında liderlik daha fazla ön plana çıkarılır, amaçlar ve buna ulaşmak için stratejiler belirginleşir, talepler netleşir.

Suriye İhvanı'nda toplumsal moral hareketten İslamcılık'a dönüşüm daha kurulma aşamasında gerçekleşmiş, Mustafa Es-Sibai “islam devleti” için yola çıkmış (Hinnebusch, 1982: 151), 1945-46 yıllarında Suriye'de İslam devleti oluşturmak amacıyla var olan örgütleri birleştirerek Suriye İhvanı'nı kurmuştur (Teitelbaum, 2004: 135). Böylece, Suriye İhvanı, Suriye'de seküler Fransız rejimine karşı ortaya çıkan İslamcı grupların bu ideoloji çerçevesinde birleşmesi ile oluşmuş (Calvert, 2009: 238) ve mevcut siyasal sistemde topyekün reform amaçlamıştır (Weismann, 2010:2-3).

Politik bir parti gibi çalıştığı ve cemiyet olma özelliğini koruduğu halde Suriye İhvanı kendisini, bunların her ikisinden ziyade, -tıpkı Mısır İhvanı gibi- hayatın bütün boyutlarını kuşatan ve İslam toplumunun bağrından çıkan bir hareket olarak tanımlar. Sibai'nin şu sözleri bu duruma işaret eder: "Bizim hareketimiz ne bir cemiyet ne de politik bir parti hareketidir. Bizimki İslam ümmetinin bütününü kuşatan bir ruhtur." (Abdullah, 1988: 110) Sibai'nin belirttiği bu ruh, temel olarak modern dünyada İslamı geniş kapsamlı bir ideoloji olarak açıkça beyan etmeyi amaçlamış, bireyi ve sosyal hayatı bütün yönleriyle içine alan, bütün sorunları çözebilecek olduğuna inanılan İslam Nizamı'na davet etmiştir. Örneğin Sibai'nin önderliğindeki Suriye İhvanı'nın çalışma programına göre, Suriye'nin sorunlarına İslamcı bir çözüm bulmak, dış güçlere bağımlılığa, feodalizme ve üst sınıfın egemenliğine bir son vermeyi, büyük devletlerin müdahalelerinden korunmayı, milli bir ekonomi yaratmayı gerektiriyordu (Abdullah, 1988: 113).

Suriye İhvanı́nın politik konumlanışını etkileyen unsurlardan biri, kuruluşunun hemen ardından, bürokratikleşme aşamasına geçerek yasal zeminde temsil fırsatını elde etmesidir. Suriye İhvanı, daha 1946 yılında Suriye Fransa'dan bağımsızlaşırken parlamenter yapıya katılabilmiş, 1945-63 arasında siyasi parti olarak örgütlenebilmiş, 1949 Darbesi'nden sonra ilk olarak "islami Sosyalist Cephe", ardından "Ihvan-ül Müslimin" adlarılla, parlamentoda temsil edilmiş, büyük partiler ve bağımsızlar tarafından desteklenmiş, iki üyesi bakan olabilmiştir. (Seale, 1965: 79). Özellikle 1947 seçimlerinde hem komünist partisine hem de Baas partisine oranla daha fazla destek görmüştür. Ülkenin iktidara talip bir unsuru iken yaşanan Baas Darbesi ve ardından rejim tarafından dışlanma İhvan'da travmatik bir değişim süreci başlatmıştır. Kendini yeniden tanımlama gereksinimi içerisinde İhvan, Baas-Sovyetler Birliği birlikteliğine koşut olarak sosyalist kimliğini bir yana bırakarak sol ile arasında mesafe koymasını beraberinde getirmiştir. İkinci olarak Olesen ve Khosrokhavar'ın toplumsal hareketler için tanımladığı yol haritasından hareketle (2009: 8), radikalleşme aşamasına geçerek, rejimin seküler uygulamalarına karşı şiddet eylemlerine başlamıştır. Her ne kadar İhvan silahlı yeraltı örgütlerle bağlantısını inkâr etmiş olsa da, rejim İhvan'a yönelik baskısını artırmış, 1980 tarihli 49 Sayılı Kanun ile İhvan yasaklanarak üyelerine idam cezası getirilmiştir. Bu radikalleşmenin sonucu, "Hama Katliamı" olarak adlandırılan 2 Şubat 1982 tarihinde Hama kentinde on binlerce insanın öldürülmesi ve ikinci kuşak yönetici kadronun topyekûn sürgün edilmesidir.

Başlangıçta Fransız sömürgeciliğine bir tepki olarak gelişen hareketin Batıya taşınması ideolojisinde Batı karşıtı yönün törpülenmesine, daha fazla demokrasi vurgusu taşıyan söylemlerin yoğunluk kazanmasına sebep olmuştur. Özellikle Hama ayaklanmasının uzun süreli etkisi, Lobmeyer'in deyimiyle (1994: 90), "demokrasinin değil, İhvan'ın siyasi amacı, ancak 
başka bir sonuca varılacak bir araç: iktidarın varsayımı" olarak görülmüştür. Suriye İhvanı her ne kadar "demokratik, batıcı, seküler" söylemlerinde ısrarcı olsa da kamuoyunu ikna etmede başarısız olmuş, söylemleri genel olarak "taktiksel" algılanmıştır. Birçok araştırmacı (George, 2003: 15; Seale, 1965:36; Friedman, 1990:78; Lobmeyer, 1991:401) İhvan'ın bu söylemlerini tamamen taktik olarak değerlendirerek örgütü "köktendinci" kategorisinde ele almaya devam etmiştir.

Suriye İhvanı'nın Baas rejimi ile başlayan aşamalı sürgün hali, öncelikli hedefler konusunda da dönem dönem örgütün manevra alanını daraltmıştır. Rejimi değiştirmek/dönüştürmek ile sürgündeki/hapisteki üyelerin özgürlüğünü/yurda dönüşünü sağlamak konjonktürel olarak ön plana çıkmıştır. Rejimle anlaşma çabalarında baskıyı sonlandırma öncelikli iken, konjonktürel şartlar elverdiğinde rejimi değiştirme/ dönüştürme birbiri yerine geçmiştir (Gürpınar, 2015: 119). Bu pozisyon, Suriye İhvanı'nın diğer muhaliflerle birlik olabilme, bu farklı grupları kendi üyelerine açıklayabilme fırsatını da sağlamıştır. Suriye İhvanı́nın yapısının sol hareketlerde olduğu gibi katı, hiyerarşik ve gizli olmayıp esnek ve dinamik bir yapıya sahip olması Atacan'a göre (2011) hareketin yıllardır varlığını sürdürmesinin en önemli sebeplerinden biridir. Bu esneklik Suriye İhvanı'nda kendini seküler karşıt gruplarla, din adamları ile iş birliği yapması biçiminde kendini gösterir (Talhamy, 2012: 33). Ancak hareketin sürgünde bile ayakta kalabilmesini sağlayan bu durum, kamuoyu desteği açısından Suriye İhvanı́nın ana hedeflerinin ne olduğu konusunda belirsizlik yaratmış, sonuç olarak hareketin sürekliliğini sağlarken, kitlesel desteğini azaltmıştır (Gürpınar, 2015: 120).

2000 'li yıllar örgüt için yeni bir sürecin başlamasını işaret etmiştir. Uluslararası konjonktürde yaşanan değişimle birlikte Sovyet desteğinden yoksun kalan Suriye/Baas iktidarı ve yönetimi yeni devralan Beşar Esad, toplumsal uzlaşma amacıyla ilk başlarda îhvan'la anlaşma yoluna gitmiştir. İhvan'da ise yönetime yeni 1996'da gelen Beyanuni, Hafız Esad iktidarını devirerek rejimi değiştirme amacını gerçekleştirmenin zorluğu ile öncelikle rejim ile uzlaşma ve sürgün/ hapisteki üyeleri için çözüm bulma çabasına girişmiş, şiddeti reddettiğini ve Esad rejimini tanıdığını açıklamıştır. Esad'ın Beyanuni'nin 3 temel isteğini (bütün İhvan üyelerinin hapisten çıkarılması, sürgündekilerin ülkeye dönüşüne izin verilmesi ve hükümetin İhvan'a yönelik yasaklamaları kaldırması) reddetmesi, Beyanuni'nin demokratik söylemlerinde bir değişim yaratmasa da stratejik bir farklıığa neden olmuş, İhvan hedeflerine ulaşmak için liberaller, komünistler, Kürtler ve iltica eden eski Başkan Yardımcısı Abdulhalim Haddam gibi seküler muhalefet ile güçlerini birleştirmeye çalışmıştır. İhvan, Ağustos 2002'de Londra'da toplanarak "Suriye Ulusal Paktı" oluşturmuş, seküler muhalafetle birlikte "Ulusal Sözleşme" hazırlayarak imzalamış, 2004 yılında ise, "Suriye'nin Geleceği İçin Siyasi Proje"yi açıklamıştır (Ghadbian, 2010). Bu metinde, Suriye'de oluşturulacak çoğulculuk, insan hakları, eşitlik, adalet, sivil toplum ve yasal yönetime dayalı politik yapı için bir program yayımlanmıştır. Söyleme bakıldığında, Suriye toplumu 20 yıl öncesine kıyasla dini değerleri ön plana çıkardıkça, İhvan'ınki sekülerleşmiştir (Talhamy,2012: 35). Bu durum Suriye İhvanı'na bağlı kitlelerde kopuşları beraberinde getirmiştir.

Arap İsyanları́nın ardından Suriye'deki gösterilerde Suriye İhvanı intiyatlı davranarak, açıkça protestoculara desteğini vurgulasa da örgütlediğini kabul etmemiş, protestoculara yönelik şiddet sona ererse rejimle diyaloğa gireceklerini açıklamışlardır (Sly, 2011). Benzer biçimde, Mayıs 2011 'de Antalya'da yaklaşık 300 Suriye muhalifi bir otelde 4 günlük konferans düzenleyerek, birleşik bir hareket yaratmaya çalışmışlardır. Burada Suriye İhvanı temsilcileri, "varlıklarının açılış seremonisinden sonra olduğunun" altını çizmiştir (Sly, 2011). Karşıt grupların katılımı ile oluşan Suriye Ulusal Konseyi (SUK) ve ardından kurulan Suriye Muhalif ve Devrimci Güçler Ulusal Koalisyonu (SMDK)'nda Suriye İhvanı azınlığı oluşturmuş ve etkisini gitgide yitirmiştir. Sürgünde oluşunun getirdiği halka ulaşma sıkıntılarını aşamayan örgütün özellikle genç üyeleri ikna etmede sorunları olmuştur. Daha dinamik, radikal gruplara katılmayı tercih eden gençler için, yıllardır ülkede olmayan üyelerinin görece yaşlı olduğu Suriye İhvanı cazip bir seçenek olmayabilir (Pargeter, 2010a: 25). Sonuç olarak, Suriye İhvanı'nın demokrasi ve insan hakları konularında Alison Pargeter'ın deyimiyle "herkesi ikna etmede uzun bir yolu olduğu" söylenebilir (Pargeter, 2010b: 102).

\subsection{HAMAS}

Mısır'da İhvan'ın kuruluşunun hemen ardından 1930'lu yıllardan itibaren, Filistin ile bağlantı sağIanmaya başlamıştır. Hasan El-Benna kardeşi Abdürrahman El Benna'yı Filistin topraklarına temaslarda bulunmak amacıyla göndermiştir. Filistin'e gelen yeni grup 1945 yılında Kudüs'te ilk şubesini açarak "Filistin kolu" ile bağlantı kurmuştur. 1947 yılına gelindiğinde Mısır'daki ana grubun yardımıyla Filistin'in diğer 
şehirlerini de kapsayacak şekilde yirmi beşe yakın şube açılmıştır. Örgüt bu yıllardan itibaren Gazze ve çevresinde etkili olmuş ve ilk olarak Filistin'deki İngiliz Yönetimi'ne karşı gelmek için eylemlerde bulunmuştur. Filistin'deki İhvan bu yönü ile Suriye İhvanı ile benzeşir, ikisi de "yabancı" yönetimlere karşı anti-emperyalist İslamcı bir karşı çıkış çerçevesinde örgütlenerek etki alanını genişletmiştir.

Filistin'deki İngiliz yönetimine karşı çıkış yerini İsrail'in kurulması ile aktif bir direnişe bırakmıştır. İhvan, bu tarihten sonra Filistin Kurtuluş Örgütü'nden (FKÖ) farklı bir taktik izleyerek "Cihat" için toplumun değiştirilmesi gerektiğini öne sürmüştür. 1936-39 yılları arasındaki Büyük Filistin Ayaklanmasından itibaren Ihvan hareketi, Filistin meselesi içinde önemli bir konuma gelmiş, 1948 yılında İsrail'in kurulmasından sonra çıkan I. Arap-İsrail Savaşı'na aktif olarak katılmıştır.

Toplumsal hareketlerin gelişmesinde özel amaçlı dernekler ve koalisyonlar oluşturma, mitingler, gösteriler ve basın açıklamaları düzenlemek etkilidir (Tilly, 2004:3). Çoğu İslamcı hareket gibi Suriye İhvanı ve Filistin İhvanı da dini okullar, yardım dernekleri, camiler, sosyal kulüpler ve spor tesisleri kurarak öncelikle İslamcı bir nesil yetiştirilmesi için çabalamıştır (Abu-Amr 1993: 7). Ayrıca kiliseler, camiler, sendikalar ve mahalleler gündelik konuların tartışıldığı yerler olarak karşımıza çıkarlar (Carroll, 2005: 13). İnsanlar gerçek anlamda sosyal değişikliği sağlamak adına dini motifleri kullanarak buralarda faaliyet gösterirler (Snow ve Cross 2011: 118). Ortadoğu coğrafyasında camiler ve mescitler örgütlerin faaliyetlerini yürütmesi için hizmet veren alanlar olması yönünden önemlidir (Olesen ve Khosrokhavar, 2009: 19-20). Camiler Müslüman toplumlar için sadece ibadet merkezi değildir, aynı zamanda eğitim, kültür, sosyal ve siyasi faaliyetleri kapsayan bir toplantı yeri olarak değerlendirilir. Nitekim Suriye İhvanı́nın kurulduktan hemen sonra gelişsmesinde etkili olan faktör, Ömer Abdullah'a göre (1988:110-1), "mükemmel bir organizasyona sahip olmanın yanı sıra, program ve adaylarını tanıtmak için camileri, pazarları ve umuma ait diğer yerleri çok etkin bir şekilde kullanmalarıdır." Filistin'de İhvan'ın yayılması ve destek kazanması için öncelikle zekât ve/ya yardımın ön plana çıkarıldığı, ibadethanelerin yanında kütüphaneler, spor merkezleri ve sosyal kulüplerin kurulmasıyla halka destek sağlandığı, üniversite bursları ve İhvan tarafından işletilen kreşler/anaokulları ile tabanın genişlediği görülebilir. HAMAS'ın çekirdeğini de yine bir hayır kurumu oluşturmuştur. 1973'te Şeyh Ahmed Yasin Gazze'de El- Mucamma El-i̇slami'yi kurarak yöneticiliğine Abdülaziz El Rantisi'nin üstlenmesiyle sosyal hizmetler bu yapıdan Filistinliler'e dağıtılmıştır. İsrail yönetimi de Mücemma'yı bir hayır kurumu olarak görmüş ve 1978 'de çalışmalarına izin vermiştir (Abu-Amr, 1993:7).

Hareketin itici gücü camiler, bu dönemde her türlü kültürel ve toplumsal etkileşime açık birer eğitim merkezi olmuştur. 1967-1987 yılları arasında, yirmi yıllık süreç içinde Gazze'deki cami sayısı 3 kat artarak 200'den 600'e çıkmıştır. 1975'den 1980'lerin ortalarına kadarki süreçte kurulan hayır kurumları, öğrenci toplukları, İslamcı kulüpler dindar gençliğin buluşma merkezleri haline gelmiştir (Baroud, 2009:122). Bu hayır faaliyetlerine ek olarak HAMAS kendine son yıllarda toplumdaki bozulmadan mustarip Filistin toplumunun ahlaki değerlerini iyileştirme misyonunu edinmiştir (Roy, 2011: 15). Suriye İhvanı'ndan farklı olarak Filistin İhvanı, siyasete doğrudan girip partileşme yerine uzun süre toplumsal örgütlenmeye önem vermiş, tabana yayılmaya çalışmıştır. Ancak bu toplumun derinine nüfuz etmeyi siyasi anlamda taçlandıran iki unsur, Oslo sürecindeki siyaseti ve Arafat'ın ölümüdür.

HAMAS'ın kuruluşunda bürokratikleşme ile radikalleşme birlikte gerçekleşmiştir. Benna'nın İhvan anlatımındaki "hükümet kurma" ve "savaş izni", HAMAS'ın çekirdeğini oluşturan Filistin İhvanı ile Suriye İhvanı'nda farklı algılanmış ve farklı pratikler yaşanmıştır. Suriye İhvanı başlangıçta rejime katıım amacını gütmüş, HAMAS ise doğrudan yeni bir sistem kurma üzerine harekete geçmiştir. Türkçe açıımı İslami Direniş Hareketi olarak bilinen Hareket-ül Mukavemetil İslamiye (HAMAS) ilk olarak 1987 yılında Mısır merkezli İhvan'ın Gazze'deki kolu olarak kurulmuştur. HAMAS, I. İntifada'dan (1987-1993) itibaren bir yandan İsrail işgaline karşı silahlı direnişi sürdürürken, öte yandan Filistin toplumu içerisinde gerçekleştirdiği sosyal hizmetlerle çok önemli bir işlevi yerine getirmiştir. Oslo Süreci ile birlikte kurulan Filistin Yönetimi'nin tam olarak yerine getiremediği eğitim, sağlık, gıda temini gibi Filistinlilerin temel intiyaçlarına dönük talepleri karşılayarak Filistinliler arasında itibar kazanmıştır. Böylece HAMAS işgal altındaki Filistin topraklarında bir yandan silahlı kanadı olan, işgale karşı direniş hareketi, öte yandan Filistin halkına sosyal destek sağlayan ve kendi özgün karakteristiklerine sahip bir toplumsal hareket, ama aynı zamanda demokratik seçimlere katılan ve bu 
seçimlerden başarıyla çıkan bir siyasal parti özelliklerinin tümünü bünyesinde toplamıştır. Robinson'ın yorumuyla HAMAS'ın tabanını genişleten, "hegemonik bir barış" olan ve Filistinlilerin haklarını gözetmekten ziyade İsrail'in egemenliğini kalıcılaştıran Oslo'ya karşı tutumu olmuştur (Robinson, 2002: 177-183).

HAMAS, Suriye İhvanı'ndan çok daha organize bir yapıya sahiptir. Şura, Siyasî Büro ile Gazze ve Batı Şeria'daki liderlik kilit yapılardır. Şura, kararların alındığı temel yapıdır ve alınan kararlar Siyasî Büro tarafından hayata geçirilir (Gunning, 2007: 99). HAMAS'ın askerî kanadını oluşturan İzzeddin El-Kassam Tugaylarının üst düzey askerî militanların idaresindeki çok sayıda yerel girişimlerden biri olarak 1991'de kurulduğu ve örgütün resmî askerî yapısı olduğu belirtilmektedir (Mishal ve Sela, 2006: 64). Ancak örgütün yönetiminde üst düzey yöneticilerin komutandan ziyade siyasi kanattan gelmeleri HAMAS liderlerinin gücünün doğrudan askerî kanadın şiddet kapasitesinden beslenmediğini göstermiştir (Gunning, 2008: 139).

HAMAS için iki hedef bütün tarihi boyunca ön plana çıkmıştır: i) Siyonist işgalin Filistin toprakları üzerindeki egemenliğinin tanınmaması, ii) Filistin'in toprak bütünlüğünden ödün verilmemesidir. Ancak FKÖ'nün bu noktalarda tavizler vermeye başlaması İslami Cihad'ın eylemlerine sempati duyan ve toplumsal dönüşüm talebinde olan genç bir nesilin ortaya çıkmasına sebep olmuştur. Singh (2012: 535), HAMAS'ın İsrail işgaline karşı silahlı direniş tarzını dinin ve milliyetçiliğin seferber güçler olarak hizmet ettiği, ideoloji tarafından beslenen "kahramanca direniş" (Heroic Resistance) olarak tanımlamıştır. Özverili eylemin inşası kahramanı topluma, toplumu da kahramana bağlar (Singh, 2012: 548). Suriye İhvanı'nda, özellikle Batıya sürgünden sonra sürekli reddedilen radikallik, HAMAS'ta benimsenerek öne çıkarılmış, askeri kanadın gerçekleştirdiği intihar eylemleri ile örgüt "kahraman"lık mitini yüceltmiştir.

Suriye İhvanı́nda yaşanan Baas karşıtlığına benzer biçimde, HAMAS'ta da FKÖ memnuniyetsizliği kitlelerin harekete katılımının artmasının itici gücü olmuştur. HAMAS direnişine yönelik olarak Meşhal "bizimki, askeri ve siyasi faaliyeti kaynaştıran kapsamlı bir harekettir. Vizyonumuz, yalnızca ikisine de odaklanmadan onları birleştirmektir. Direniş, işgali sona erdirmek, toprak ve haklarımızı geri kazanmak için stratejimizin temel bir parçasıdır, ancak bu strateji aynı zamanda siyasi ve popüler eylem, medya çalışması ve diplomasi içermektedir" diyerek HAMAS'ın şiddet/diplomasi ikiliğini açıklamıştır (Rabbani, 2008:
64). Gunning'in (2007: 144-5), "iki başlı strateji" olarak adlandırdığı HAMAS'ın askeri yönünün yanı sıra Filistin topraklarında kurmuş olduğu güçlü sosyal ağ, HAMAS'ın seçim zaferleri aracılığıyla siyasi güce yükselmesini sağlamıştır. 1990'larda yerel işgücü ve öğrenci sendikası seçimlerinde başarılı adımlar, 2006 Filistin Yasama Konseyi (PLC) seçimlerinde HAMAS'ı zafere taşımıştır.

1990'larda HAMAS'ın güç kazanması El-Fetih ile rekabet içerisine girmesine neden olmuştur. Bu rekabeti destekleyen İsrail, HAMAS'a yumuşak davranarak böl-yönet politikası uygulamış, örneğin FKÖ gösterilerini yasaklamış, HAMAS gösterilerine izin vermiştir. HAMAS aynı zamanda FKÖ'nün laik siyasi programını da tartışmaya açmış, dini doktrinle beraber güncel sorunları da harmanlamayı başarmıştır. Müzakereleri önemseyen FKÖ'ye karşıt, HAMAS'ın politik mücadeleye katılmaması ve intifada boyunca silahlı eylemlere ağırlık vermesi mobilizasyonu sağlamak açısından daha işlevsel olmuş, İsrail ile siyasi pazarlık yapan El-Fetih'in siyasal alanda yalnız kalmasına sebep olmuştur. HAMAS'ın bağımsız hareket etme tercihi HAMAS'A manevra alanı sağlamış, Filistinli kitlelerle temasında belli bir esneklik kazandırmıştır. Oslo yılları boyunca barış sürecinin seyrine göre HAMAS izlediği direnişin ve silahlı mücadelenin dozunu ayarlamıştır. Barış konusunda umutlu olunan 1998, 1999 ve 2000 yıllarında HAMAS neredeyse hiç intihar eylemi yapmamış, sosyal yönde çalışmalarını öne çıkarmıştır. Oslo sürecinin çıkmaza girdiği 2000'lerin başı itibariyle HAMAS silahlı eylemlerini iyice artırarak, İsrail'e yönelik artan öfkeyi kullanıp kaynak mobilizasyonunu hızlandırmış ve yeni kuşakların El-Fetih'e değil HAMAS'a katılmalarını sağlamıştır. Sonuçta Filistin toplumu arasında Oslo Süreci'nin iflas ettiği anlaşıınca FKÖ başarısızlığı ile yalnız kalırken HAMAS süreç boyunca sergilediği esnek yaklaşımdan dolayı Filistin siyaseti içerisinde oldukça güçlü bir yer edinmişti. Bu yükselişte 2004 yılının Kasım ayında Yaser Arafat'ın ölümü HAMAS-FKÖ rekabetinin de önemini yitirmesine, HAMAS'ın alternatif bir hareketten iktidara doğru yönelmesine sebep olmuştur. On yıllık ateşkes ilan ederek yerel seçimlere giren HAMAS Gazze, Kalkilya, Nablus gibi bölgelerde birçok sandalye kazanmıştır. 25 Ocak 2006'da yapılan parlamento seçimlerinde bu başarı taçlanmış, HAMAS 132 sandalyeli Filistin Meclisi'nde 74 sandalye kazanırken, Filistin lideri Mahmud Abbas'ın El-Fetih hareketi 45 sandalyede kalmış, sonuçta HAMAS siyasi bir unvanla uluslararası kamuoyunda "HAMAS Heyeti" kimliği ile temsil yetkisi kazanmıştır. 


\section{SURIYE IHVANI VE HAMAS'TA “ORTAK DÜŞMAN" ALGISI}

Politik olarak uygulamada daha eskilere gitse de "Devleti korumanın, ayaklanmalara, isyana, iç savaşa karşı güvenceye almanın en iyi yollarından birinin, kitleleri birbirleriyle yakınlaştırmak ve ortak neden oluşturabilecekleri bir düşman bulmak" olduğu düşüncesi Jean Bodin'den (1955: 168) beri ileri sürülmüştür. Sosyal bilimlerde birçok disiplinde ortak düşman kavramına değinen birbirinden farklı yaklaşım vardır. Ortak düşman kavramına ilişkin çalışmalar, ortak düşmanın, doğal bir felaket ya da akıllı bir düşman biçiminde ortaya çıkışına, ajanların kolektif olarak hareket etme olasılığını artırmasına değinmiştir. Psikoloji ve sosyolojide, böyle bir ortak düşmanın varlığının, temsilcilerin tercihlerini, örneğin; dayanışma duygularını arttırdığına vurgu yapılmıştır. Toplumsal hareketler, kendi kitlesini genişletmek ve/veya pekiştirmek için ortak düşmana karşı işbirliği politikasını ön plana çıkarabilirler. Waltz'ın belirttiği gibi (1959: 163), daha geniş kitlelere etki etmek isteyen yapı, öncelikle kendi kimliğini, ardından rakibini tanımlayarak, bir düşman yaratabilir.

Uluslararası ilişskiler "ortak düşman"a alternatif bir kavramsallaştırmayla bunu "günah keçisi hipotezi" ismiyle dış politika teorisi olarak kullanmıştır (Levy, 1989; Sirin, 2011). Buna göre hükümetler dış düşman yaratarak, ya da dış "günahkeçisi" bularak "içerideki" amaçlarını gerçekleştirmeye çalışırken, buna bir gerekçe ya da iç tutarlılık sağlarlar (Levy, 1989: 260). Sosyolojide, Simmel (1955) ve Coser (1956), ortak düşmanın varlığının grup içinde uyumu artıracağını belirtmiştir. Simmel (1955) ortak bir düşmanla yüz yüze gelmenin, ortak noktası olmayan diğer insanları bile bir araya getirebileceğini iddia etmiştir. Bu düşünce çatışmanın sosyolojisinde bir gerçekliğe dönüşürken, bazı teorisyenler bunu olası bir sonuç olarak ele alırlar. Coser (1956: 92), dış çatışmanın bir grubu bir araya getirme eğiliminde olduğunu, bununla birlikte merkezileşme ile sonuçlanmasının hem çatışmanın niteliğine hem de grubun önceden var olan fikir birliğine bağlı olduğunu belirtmiştir. Diğer çalışmalar, dışsal çatışmanın iç birliği oluşturması için, bir grubun dış tehditle karşı karşıya kalırken, üyelerini destekleme kapasitesi ve liderlik gerektirdiğini ileri sürmektedir (Stein, 1976). Bu yazında paylaşılan görüş, ortak düşman olgusunun gruptaki psikolojiyi veya tercihleri değiştiriyor olmasıdır.

İhvan henüz kuruluş aşamasında ortak düşman tanımlaması ile yola çıkmış, İngiliz hâkimiyetine karşı örgütlenme ile hareket başlamıştır. Ardından Filistin ve Suriye İhvanı da "yabancı"/Müslüman olmayan hâkimiyete yönelik olarak ortak düşman üzerinden yükselmiştir. Her iki toplumsal hareket de değişim için kendi vizyonlarını İslamcı figürleri kullanarak sergilerken onların deyimiyle kâfirlere karşı şiddet kullanmayı meşrulaştırarak (Olesen ve Khosrokhavar, 2009: 9) "öteki" tanımlaması üzerinden güçlerini artırmıştır. Kamuoyunu harekete çekmek ve kolektif eylemin haklılığını göstermek için "Biz ve Onlar" ayrımı yapılarak kolektif kimlikler yaratılmıştır.

HAMAS'ın kuruluşunda İsrail ortak düşmanlığı ön plandadır ve tarihi boyunca sürekliliğe sahiptir. Ancak Fransa'nın bölgeden çekilmesi Suriye İhvanı'nda ortak düşman algısının sönümlenmesine neden olmuştur. Baas iktidarı "ortak düşman" figürünü doldurmak için yetersizdir, HAMAS'taki Müslüman olmayana karşı "cihat" yapma vurgusu, Suriye ìnvanı'nda karşılıksız kalmıştır. Kaldı ki, Suriye İhvanı́nın Batı'da sürgünde iken, "cihat" söylemleri yapması kendi varlığının devamlılığı açısından problemlidir. Bu sebeple Suriye Ihvanı, Batılı değerleri ön plana çıkararak, bölgesel konumunu güçlendirmeyi tercih etmek durumunda kalmıştır. Kendi tanımlamasında kullandığı Batılı değerler, "ortak düşman" söylemi ile doğrudan çelişkilidir.

Suriye İhvanı'nın kendini tanımlamada yaşadığı çelişki ortaya koyduğu ideolojide, politikalarda tam anlamıyla netliğe kavuşamaması Suriye İhvanı́nın ortak düşman yaratamamasının en önemli nedenlerinden biri olabilir. Batı'da yer alıp, Batı'dan destek almaya çalışırken demokrasi ve insan hakları vurgusunun ön planda oluşu, kamuoyu nezdinde yeterince ikna edici olmamıştır. Ikinci olarak, düşmanını tanımlamada netliğe kavuşamaması, rejime dönük söylemlerindeki geçişler, kendi üyeleri için rejimle pazarlık yapmaları, ortak düşman algısının oluşmasını tamamen engellemiş, inandırıcılığını zedelemiştir. Sürgünde ve yasaklı olmanın kamuoyuna ulaşmada yarattığı engellere ek olarak bütün bu sebeplerle Suriye İhvanı halkı sürükleyecek dinamizmden yoksun kalmış ve Suriye'nin geleceğinde söz sahibi olamamıştır.

Suriye İhvanı radikalleşmeyle arasına her zaman mesafe koyarak şiddet eylemlerini üstlenmemişken HAMAS'ta cihat fikri her zaman ön planda olmuştur. Filistin'de İhvan, Arap-İsrail Savaşı'na katılarak kitleselleşmiş, HAMAS kuruluşundan itibaren şiddet eylemleri ile yükselmiştir. HAMAS kendini İsrail'in işgali altında, ortak düşman İsrail'e karşı var olma savaşı veren bir konumda tanımlarken, Suriye İhvanı'nın 
karşıtı Baas rejimidir. Suriye İhvanı, Baas'a karşı cihat kartını kullanma olanağından yoksundur, kaldı ki hareketin sürgündeki konumu söylem ve eylemlerinde radikalliğin sınırlandırılması sonucunu doğurmuştur. Suriye İhvanı'nın "ortak düşman" algısını yaratamaması hareketin yükselişine ket vuran önemli bir unsur olabilir.

Batılı değerlerle ön plana çıkmaya çalışan Suriye İhvanı'nın gelecek dönemde ortak düşman politikasını ne ölçüde ve kime yönelik uygulayabileceği Baas rejimi ile ilişkilerini yeniden tanımlamadan cevaplandırılamayacaktır. Mısır İhvanı ve diğer ülkelerdeki İhvan hareketlerinin günümüzde geldiği konum her iki örgütü doğrudan etkilemektedir. HAMAS'ın pozisyonuna bakıldığında, her ne kadar seçimleri kazanmış olsa da bir bölgede yönetimle sınırlı kaldığı görülebilir. İhvan'ın uluslararası alanda tenzili rütbesi, HAMAS'ı da derinden etkileyerek, kendini yeniden tanımlamasının yolunu açmıştır. Köklere bağlılığın sorunlu hale geldiği konjonktürde, HAMAS, İhvanı deviren Sisi iktidarı ile ilişki kurmaktadır. Bu politikanın, ileride kamuoyu nezdinde nasıl karşılanacağı soru işaretidir.

Müslüman olmayan bir "ortak düşman"a yönelik tutumunu cihat ile bütünleştirerek uygulayan HAMAS için hep ortak düşman İsrail olarak kavramsallaştırılmış, kullanılmış ve kamuoyu tarafından benimsenmiştir. HAMAS ile İsrail arasındaki sıcak çatışma, askeri kanada sahip HAMAS için "ortak düşman" söyleminin işlevselleşmesine katkıda bulunmuştur. Daha kuruluş aşamasında HAMAS, "Bizim savaşımız Siyonist işgale karşı" diyerek, meşru müdafaa hakkı üzerinden bir söylem inşaa etmiştir (Singh, 2011: 123). Kaldı ki, İsrail'in de benzer söylemleri ve şiddeti HAMAS'ın ortak düşman algısını perçinlemiş ve inşanın devamlıı̆ı̆ını sağlamıştır. Sonuçta, bir yönüyle, HAMAS'ın başından beri Lewis'in İslamcı örgüt ayrımındaki "aktivist" pozisyonda yer alırken, Suriye İhvanı́nın "Iımlı" yönü kamuoyu oluşturmada yetersiz kalmasını beraberinde getirmiştir.

Önyargının Doğası (The Nature of Prejudice) adlı eserinde Gordon Allport (1954), ortak düşmanın grubu güçlendirse de vurgunun karşıtlıktan çok güvenlik ihtiyacına yönelik olmasının önemli olduğunu belirtmiştir. Nazi Almanyasını örnekleyerek, realist bir açıklama ile "Almanlar'ın Nazilere yönelik inanışı, sadece güvenlik değil umuda yönelik olan bireysel bir ihtiyaçtan kaynaklanıyordu" demiştir (1954:182). Bu anlamda Suriye İhvanı́nın kamuoyu desteği sağlamada yetersizliğinde, demokrasi, insan hakları ve kadın politikalarının gerektiği kadar açık olmayışı, kitleyi umuda sevk edememesi etkili olmuş olabilir. Diğer yandan, kamuoyu oluşturmanın ilk şartı olan iletişim kanallarının açık olması konusunda Suriye İhvanı dezavantajlı konumdadır. Suriye'den sürgün edilmiş olması ve ülke içerisindeki yasaklı konumu kamuoyu oluşturmasını zorlayan birincil nedendir. HAMAS ise kurulduğu andan itibaren kendi kimliğini karşıtlık üzerinden inşa ederek, yeni bir "umut" olmayı başarmış, ülkede önemli bir kitle desteği sağlamıştır.

\section{SONUÇ}

Suriye İhvanı ve HAMAS'ı toplumsal hareketler ve ortak düşman tanımlaması üzerinden karşılaştıran bu çalışmada varılan birkaç sonuçtan bahsedilebilir. Iki hareketin kitlelere yayılması işgale ve baskıya maruz kalan halkın direnişi ile gerçekleşmiştir. Suriye örneğinde, bu baskı ilk olarak Fransa'dan gelse de, hareketi büyütüp geliştiren esas olarak Baas rejiminin yarattığı ortamdır. HAMAS da Filistin halkı da bu genel kuralın dışında değildir. Öncelikle İngiliz manda yönetimine isyan, İsrail'in saldırıları ile El Fetih'in yetersiz kalışı HAMAS'ın güç kazanmasının ardındaki zemini yaratmıştır. Bir başka deyişle içinde bulunduğu tarihi ve sosyo-politik koşullar, gerek bu direniş hareketinin ortaya çıkmasında gerekse onun kullandığı taktik, söylem ve yöntemlerde belirleyici bir rol oynamıştır.

Öncelikle her iki hareket de pragmatik ve rasyoneldir, zaman içerisinde belirgin bir esnekliğe sahip olarak strateji geliştirmiştir. Suriye İhvanı nasıl duruma göre birincil önceliklerini şekillendiriyorsa, HAMAS da özellikle Oslo sürecinde görülebileceği gibi, şartlara uyum sağlayabilmiştir. Ancak HAMAS, özellikle Oslo sürecinde ne istemediğini, kiminle anlaşmayacağını açık bir biçimde tanımlamış, sadece direniş/şiddet seçeneklerinde esneklik sergilemiştir. Suriye İhvanı ise, karşıtı Baas rejimi ile kimi zaman kendi üyelerinin affı için diyalog kurabilmiş, tanımlamalarında esnek davranmıştır. HAMAS'ın esnekliği daha çok stratejilerine yönelikken Suriye İhvanı politikalarında esnekliğe gitmiş, bu da kamuoyu nezdinde eleştirel karşılanmıştır.

İvan hareketinin camiler, dernekler, yardım faaliyetleri yoluyla topluma derinden nüfuz etmesi her iki örnekte de görülebilir. Ancak Suriye İhvanı'nın ilk toplumsal hareket olarak ortaya çıkışından kısa süre sonra siyasal alana geçebilmesi, HAMAS örneğinde yaşanmamıştır. 1930'lardan itibaren Filistin topraklarında faaliyet gösteren İhvan, yıllar boyunca bir sivil toplum kuruluşu gibi topluma derinden 
nüfuz edebilmiştir. Dolayısıyla, HAMAS'ın bu derin toplumsal bağın üzerinden yükseldiği görülür. Oysa Suriye İhvanı Baas rejimi ile Suriye'den aşamalı olarak tasfiye edilmiş, dolayısıyla toplumla bağlarını HAMAS kadar kuramamıştır. Bu sebep HAMAS'ın ve Suriye İhvanı́nın bugün geldiğimiz noktadaki konumunu anlamamız için bir anahtar olabilir.

\section{KAYNAKLAR}

Abdullah, Ö. F. (1988) Suriye Dosyası, Akabe Yayınları, İstanbul.

Abu-Amr, Z. (1993) "Hamas: A Historical and Political Background", Journal of Palestine Studies, Vol. 22, No. 4: 5-19.

Allport, G. W. (1954) The Nature of Prejudice, Addison-Wesley Publishing Company, Cambridge.

Atacan, F. (2011), "Fulya Atacan'la Arap Baharı Üzerine Söyleşi”, Asım Öz, Praksis, 26. Sayı - Siyasal İslam, İktidar ve Hegemonya: 31-54.

Baroud, R. (2009) My Father Was a Freedom Fighter: Gaza's Untold Story, New York: Pluto Press.

Bayat, A. (2005) "Islamism and Social Movement Theory", Third World Quarterly, Vol. 26, No. 6, s. 891-908.

Bodin, J. (1955) Six Books of the Commonwealth, Basil Blackwell, Oxford.

Bulut, F. (1994) İslamcı Örgütler; Tüm Zamanlar Yayıncılık, İstanbul.

Calvert, J. (2009) Sayyid Qutb and the Origins of Radical Islamism, Columbia University Press, New York.

Carroll, W. (2005) Hamas and the Arab State: A Transnational Terrorist Social Movement's Impact on Regimes in the Middle East. Unpublished Thesis, Philadelphia: Haverford College.

Christiansen, J. (2009) "Four Stages of Social Movements", Research Starters:1-7.

Coser, L. A. (1956) The Functions of Social Confict, New York: Free Press.

Çetinkaya, D. (2008) Toplumsal Hareketler, Tarih, Teori ve Deneyim, İletişim Yayınları, İstanbul.

Friedman, T. L. (1990) From Beirut to Jerusalem, New York: Doubleday.

George, A. (2003) Syria: Neither Bread nor Freedom, London: Zed Books.

Ghadbian, N. (2010) "Syria's Muslim Brothers: Where to Next?" The Daily Star, Beirut, Sept. 17, 2010. http://www.dailystar. com.lb/Opinion/Commentary/Sep/17/Syrias-MuslimBrothers-Where-to-next.ashx\#axzz2 GFi2UQMI (erişim tarihi: 27.11.2016).

Giddens, A. (2006), Sociology, Polity Press, United Kingdom.

Goodwin, J ve Jasper, J.M. (2003) The Social Movements Reader Cases ve Consepts, Blackwell Publishing, United Kingdom.

Gunning, J. (2007) Hamas in Politics: Democracy, Religion, Violence, Hurst Publishers Ltd., London.
Gürpınar, B. (2015) "Sürgünde Örgüt: Suriye İhvanı”, Marmara Üniversitesi Siyasal Bilimler Dergisi, Cilt 2, Sayı 1, Mart: 115-132.

Hinnebusch, R. A. (1982) "The Islamic Movement in Syria: Sectarian Conflict and Urban Rebellion in an Authoritarian Populist Regime", Ali E. Hillal Dessouki (ed.), Islamic Resurgence in the Arap World, Praeger, New York: 138-169.

Hürriyet, 2004, "HAMAS: Misilleme İsrail'de Deprem Yaratacak”, 22.03.2004.

Karaman, H. (2012) "Müslüman Kardeşler", Yeni Şafak, 13.05.2012.

Levy, J. S. (1989) "The Diversionary Theory of War: A Critique", M. M. Midlarsky (ed.) Handbook of War Studies, London: Unwin Hyman: 259-288.

Lewis, B. (1986) "On the Quietist and Activist Traditions in Islamic Political Writing", Bulletin of the School of Oriental and African Studies, University of London

Vol. 49, No. 1, In Honour of Ann K. S. Lambton, 141-147.

Lobmeyer, H. G. (1991)“Islamic Ideology and Secular Discourse: The Islamists of Syria," Orient, Vol. 32, No. 3: 395-418.

Mishal, S. ve Sela A. (2006) The Palestinian Hamas: Vision, Violence, and Coexistence, Columbia University Press, New York.

Olesen, T. ve Khosrokhavar, F. (2009) Islamism as Social Movement, Aarhus: Department of Political Science, Aarhus University Press.

Pargeter, A. (2010a), The Muslim Brotherhood: The Burden of Tradition, Saqi Books, London

Pargeter, A. (2010b) The Muslim Brotherhood: From Opposition to Power, Saqi Books, London.

Rabbani, M. (2008) “A Hamas Perspective on the Movement's Evolving Role: An Interview with Khalid Mishal: Part II", Journal of Palestine Studies, Vol. 37, No. 4: 59-81.

Robinson, G. E. (2002) "Güçlünün Barışı”, Carey, R. (Der.), Yeni Intifada: Israil'in Apartheid Politikasına Direnmek, Everest, İstanbul, s. 177-183.

Roy, O. (2005) Siyasal İslamın Iflası, Metis Yayıncılık, İstanbul.

Roy, S. (2011), Hamas and Civil Society in Gaza: Engaging the Islamist Social Sector, Princeton University Press, Princeton.

Seale, P. (1965) The Struggle for Syria: A Study of Post-War Arab Politics 1945-1958, Oxford University Press, London.

Simmel, G. (1955) Conflict and the Web of Group-Affiliations, New York: Free Press. 
Singh, R. (2011) HAMAS and Suicide Terrorism, Routledge, London\&New York.

Singh, R. (2012) "The Discourse and Practice of 'Heroic Resistance' in the Israeli-Palestinian Conflict: The Case of Hamas", Politics, Religion \& Ideology, 13, no. 4: 529-545.

Sirin, C.V. (2011) "Is It Cohesion or Diversion? Domestic Instability and The Use of Force in International Crises", International Political Science Review 32: 303-321.

Sly, L. (2011) "Syrian Opposition Unites in Exile”, Washington Post, 2 Haziran, http://www.washingtonpost.com/world/ middle-east/syrian-opposition-unites-in-exile/2011/06/01/ AGjEEoGH_story.html (Erişim Tarihi: 27.12.2016).

Snow, D. A., Cross, R. (2011) "Radicalism within the Context of Social Movements: Processes and Types", Journal of Strategic Security, 4(4): 115-130.

Stein, A. (1976) "Conflict and Cohesion: A Review of the Literature." Journal of Conflict Resolution 20 (1): 143-72.

Talhamy, Y. (2012) "The Syrian Uprising: The Muslim Brotherhood Reborn", Middle East Quarterly, Spring: 33-47.
Teitelbaum, J. (2004) "The Muslim Brotherhood and the 'Struggle for Syria', 1947-1958, Between Accommodation and Ideology", Middle Eastern Studies, Vol. 40, No.3, May: 134-158.

Tekin, Y. ve Akgün, B. (2011) “íslamcılar-Demokrasi İlişkisinin Tarihi Seyri", İslamcılık, İletişim Yayınları, İstanbul.

Touraine, A. (2000) Can We Live Together?: Equality and Difference, Stanford, Calif: Stanford University Press.

Tilly, C. (2004) Social Movements 1768-2004. Boulder, Colorado, USA: Paradigm.

Tarrow, S. (1994) Power in Movement: Social Movements, Collective Action and Politics, Cambridge University Press, Cambridge.

Waltz, K. N. (1959) Man, the State, and War: A Theoretical Analysis, New York: Columbia University Press.

Waltz, K.N. (1979) Theory of International Politics. Reading, Addison-Wesley.

Weismann, I. (2010) "Democratic Fundamentalism? The Practise and Discourse of The Muslim Brothers Movement in Syria", Muslim World, 100: 1-16.

Wiktorowicz, Q. (2004) Islamic Activism A Social Movement Theory Approach, Indiana University Press, USA. 